\title{
REVIEW \\ Agroecological initiatives in Hungary and their Central European aspects
}

\author{
András Székács ${ }^{1}$, Péter Roszík², Katalin Balázs ${ }^{3}$, László Podmaniczky $^{4}$, and \\ Apolka Ujj ${ }^{4}$ \\ ${ }^{1}$ National Agricultural Research and Innovation Centre, Agro-Environmental Research Institute. Herman \\ Ottó u. 15, H-1022 Budapest, Hungary. \\ ${ }^{2}$ Biokontroll Hungária Ltd. Oroszvég lejtö 16, H-1112 Budapest, Hungary. \\ ${ }^{3}$ Geonardo Environmental Technologies Ltd. Záhony u. 7. Building D, H-1031 Budapest, Hungary. \\ ${ }^{4}$ Szent István University, Faculty of Agricultural and Environmental Sciences, Institute of Nature \\ Conservation and Landscape Management, Department of Organic Farming and Agri-Environmental \\ Planning. Páter Károly u. 1, H-2100 Gödöllö, Hungary.
}

\begin{abstract}
A. Székács, P. Roszík, K. Balázs, L. Podmaniczky, and A. Ujj. 2020. Agroecological initiatives in Hungary and their Central European aspects. Int. J. Agric. Nat. Resour. 216-234. Agroecology initiatives were first implemented within Central and Eastern Europe in Hungary in the 1980s in response to the environmental and ecological problems of intensive, agrochemical-based agricultural technology. The agroecology sector has grown substantially ever since and is currently facing its second boom, yet Hungary's level of organic farming remains substantially below the average level in the European Union (EU) and in the Visegrad Group countries (the Czech Republic, Hungary, Poland and Slovakia). This review summarizes early and recent agroecology developments in Hungary in the context of the region and the EU in a broader sense, mainly regarding scientific research and policy aspects. The 10-fold growth of the organic agriculture sector in Hungary over the last two decades brings Hungary somewhat closer to the average EU level and is discussed in relation to the regulating legal environment, i.e., the EU's harmonized Rural Development Program. In addition, the European Green Deal envisions a reduction in pesticide use by $50 \%$ by 2030 and supports agroecology to reduce excess fertilization, increase organic farming and reverse biodiversity loss. Hungary pursues these goals through, among others means, the transnational joint initiative of the Visegrad countries, BIOEAST. The environmental risks jeopardizing agroecology are summarized in a systematic context, covering not only agricultural organic microcontaminants but also agricultural biotechnology products and issues in energy utilization efficacy. Related past and current research projects, as well as Hungary's involvement in the international advancement of agroecology, are outlined.
\end{abstract}

Keywords: Organic agriculture, policy, project, research, risks, Rural Development Program.

Received Jun 05, 2020. Accepted Dec 01, 2020.

Corresponding author: szekacs.andras@akk.naik.hu 


\section{Introduction}

Agroecology is conceptualized as having three major aspects: it is part scientific discipline, part social movement and part practical application of traditional farming knowledge combined with the innovative solutions of today (Wezel et al., 2009). The weighting of these three components is different on each continent, varying largely from country to country, and may change over time depending on many factors, such as political context and research programs, or in extreme situations such as epidemics affecting the entire food system. These three aspects of agroecology cannot be separated from each other since agroecological science includes research on the environmental effects of agricultural technologies (traditional or modern), the policy aspects incorporate research outcomes into applied regulatory decision-making and the social movement facilitates the understanding of agroecology principles and pushes policy towards agroecology, among other reasons (Altieri, 2018; Moudrý et al., 2018).

At the practical level, agroecology aims to strengthen and apply natural processes that benefit production as a response to environmental contamination and problems with ecological balance. The advantages of agroecology for the environment and ecosystem services are main driving forces for its acceptance, but the apparent crises of agrochemical-based agricultural technologies also contributed to the shift, both scientific and societal, towards agroecology. An example of the crisis of agrochemicals is the reregistration process of glyphosate in the European Union (EU), which also affects society (Székács \& Darvas, 2018).

This review describes the development of agroecology from the perspective of research on environmental science and ecology, as well as policy issues in Hungary, and is embedded in the region-specific context of Central Europe. The approaches, research projects and policy programs are summarized and depicted on a timeline (Figure 1). However, the review does not attempt to summarize recent developments in agroecology as a social movement (apart from presenting projects that support the social approach of agroecology), as this aspect has been appraised by the Hungarian civilian activist group Védegylet and contracted by Agroecology Europe as a follow-up project on mapping European agroecology (Wezel \& Bellon, 2018; Gallardo-López et al., 2018; Moudrý et al., 2018).

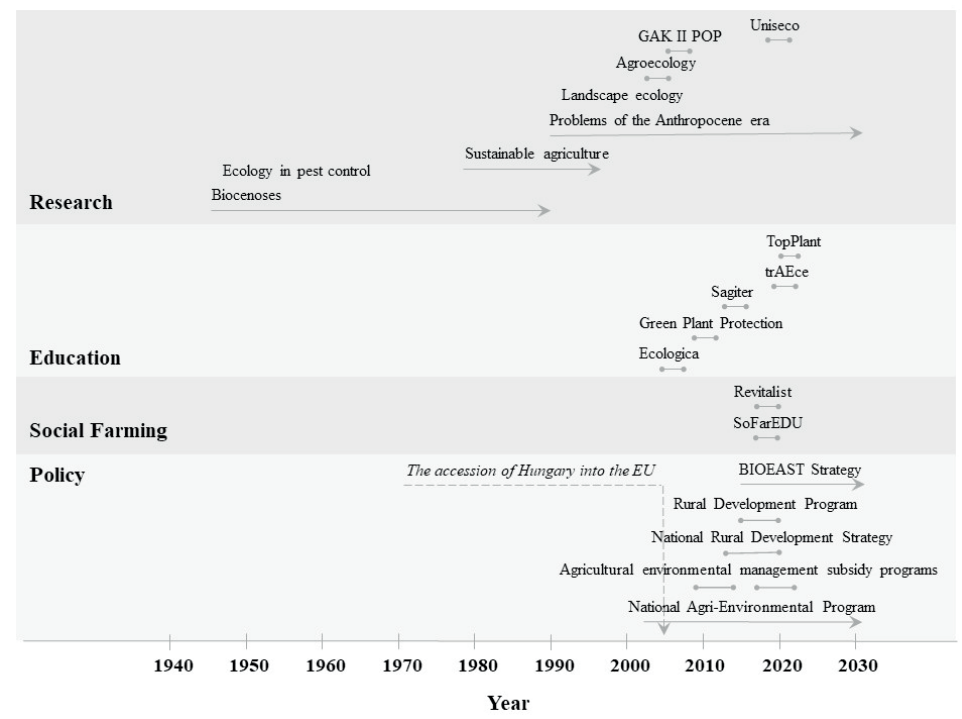

Figure 1. Timeline of scientific approaches, research projects, and educational, societal and policy programs related to organic agriculture and agroecology in Hungary. 


\section{Early initiatives related to the agroecology concept in Hungary}

The concept of agroecology emerged quite early in Hungary in the ecological (descriptive biology) and agricultural systems contexts. The eminent ecologist János Balogh, being involved in fundamental, functional and applied ecology, described in detail the structure of biocenoses, the smallest compositional units of symbioses, emphasizing their role in certain ecosystems (Balogh, 1946). Biocenoses were functionally analyzed in the context of plant protection (Szelényi, 1955; Jermy, 1956). As early as 1957, the Hungarian agro-zoologist researcher Barnabás Nagy emphasized the importance of ecology in the development of pest control methods that included biological control (Nagy, 1957). Even though he preceded the internationally reputed publication of Stern et al. (1959) by two years, his pioneering findings introducing the concept of integrated plant protection were unfortunately only described in Hungarian. His statements and findings were practically identical to those by Stern et al. Geneticist-evolution biologist Gábor Vida highlighted the fundamental differences between natural and artificial ecosystems (Maynard \& Vida, 1990; Vida, 1996). His efforts greatly contributed to the expansion of knowledge on ecological agriculture and the development of agroecology in Hungary, as well as the concept of the Anthropocene era with its theoretical, practical and societal aspects. The ecological approach has been elaborated in the context of biological plant protection (Darvas et al., 1999), soil science (Várallyay et al., 1985, Várallyay, 2010), sustainability science and landscape ecology (Kulcsár et al., 1995). This research aimed to harmonize the aspects of agriculture and the environment and resulted in the development of the land use zoning system of Hungary (Ángyán et al., 2003). The main question of the study was how to harmonize the land use of areas with low agricultural potential or changed degrees of intensity with the demand for environmental protection and natural conservation of land. The
National Agri-Environmental Programme in 2002 was based on the results of the land-use zoning research and was implemented by domestic sources two years before the country's accession to the EU. In addition, several other studies and projects relied on the results of the zoning system research, including the assessment of the European Land Information System for Agriculture and Environment (Podmaniczky et al., 2007) and the impact assessment of land-use change on soil quality in Europe (Podmaniczky et al., 2011), as well as the teaching of good practices in agroecology (Ujj et al., 2013, 2018; Ujj \& Bálint, 2015; Moudrý et al., 2018).

\section{The Rural Development Program}

In general, agroecology initially dealt primarily with crop production and protection aspects, while new dimensions such as social, economic, and ethical aspects have recently become relevant (Wezel et al., 2009). In Hungary, agroecology has long been identified with organic agriculture but not necessarily with the form of farm management operating under a control and certification system; rather, it has been associated with good practices that consider environmental protection and the ethical and social aspects of farming and apply the typical ecological agriculture sales method (e.g., community-supported agriculture, box schemes). Agroecology initiatives also aim to maintain and foster biodiversity, to protect soil and water and to uphold humus-conserving cultivation techniques. Nonetheless, the support scheme also sustains certified organic agriculture (see below).

The current Rural Development Program of Hungary (2014-2020) focuses on restoring, preserving and enhancing ecosystems; promoting social inclusion, poverty reduction, and economic development in rural areas; and promoting food chain organizations and risk management in agriculture. Among others, knowledge transfer and innovation in agriculture, ecosystem man- 
agement, social inclusion and local development are predefined priorities of the program, together providing the main policy environment for agroecology development. This program was also facilitated by the current National Rural Development Strategy (2012-2020) of the Hungarian government (Ángyán, Czene \& Tátrai, 2012). Similar rural development programs, e.g., in Romania (Fieldsend et al., 2017) and the Visegrad Group countries (the Czech Republic, Hungary, Poland and Slovakia) (Dvořáková Líšková, Klufová \& Rost, 2019) differ somewhat in their specific objectives. The Hungarian Rural Development Program, governed by corresponding ministerial decrees (Hungarian Ministry of Agriculture and Rural Development (2009a, 2009b)), established the agricultural environmental management subsidy system for agroecology in two periods, 2009-2014 (VP AKG1) and 2017-2021 (VP AKG2).

Within the framework of the Hungarian Rural Development Program, a very important source of support for ecological objectives is the scheme titled 'Conversion to ecological farming, maintaining ecological farming' (“ÖKO”), which is a government support system whereby voluntary participants undertake to carry out additional activities in their farming (e.g., conducting obligatory soil analyses and using green/stable/bacterial manure and engaging in optional activities such as conducting extended soil analyses and medium depth soil tillage; utilizing crop protection forecasting; growing pesticide-free, permanent green fallow/ bee pasture edges; using officially certified seed; and implementing no till agriculture) to achieve ecological farming objectives. The purpose of the scheme is, on the one hand, to encourage the conversion of agrochemical-based agricultural areas to organic farming and, on the other hand, to maintain farming practices in organic areas. The supported farms are obliged to follow the cross-compliance, greening, and ÖKO minimum requirements (Ujj \& Bálint, 2020).

The program poses substantial environmental/ ecological requirements and includes strict control measures by both the national support fund and the EU, and it has already resulted in significant environmental achievements in effective nutrient management and the reduction of pesticide-based technologies. Due to the harmonized legal measures of the EU (EP, 2013), agricultural subsidies can be provided only to cultivation parcels registered in the Agricultural Land Parcel Identification System (MePAR). The agricultural parcels registered in MePAR are linked to the actual user of the land and not to the owner and are determined on the basis of the area actually cultivated. As a consequence, the boundaries of the agricultural parcels may vary from year to year depending on the cultivation type or crop structure (e.g., variations due to crop rotation and fallow land). Hungary's lag behind the countries of Western Europe with respect to agroecology development is substantial, but rapid improvements are taking place. Particularly popular is the application of green and stable manure, as well as mineral and microbial soil additives, even though the effects and their corresponding modes of action are not always well defined.

\section{Organic agriculture as a segment of agroecology}

Organic farming has been an important and a historical part of agroecology initiatives. Although organic farming has been established on the ethical basis of four major principles (health, ecology, fairness, and care), its main technical emphasis, at least in a legal context, has been the practice of inspection management. Certain authors warn about the possibility of unfavorable characteristics of intensive agriculture being reproduced under an organic scenario through conventionalization of organic agriculture (De Wit \& Verhoog, 2007). Indeed, the linear business model contradicts true sustainability; therefore, the model has to be limited by environmental ethics. In Hungary, the risk of overconventionalization is rather low: the market of organic produce is still characterized by short food 
supply chains and often personal trust between the farmer and the consumer, particularly in the case of community-supported production and box distribution schemes. These factors help maintain the ethical principles of organic farming. At the same time, organic farming is currently the only legally established and certified division within agroecology.

Hungary was the first country within Central and Eastern Europe where organic farming was introduced. The different aspects of organic production are subject to uniform regulations all over the world, including in the EU (EC, 2007, 2008a, 2008b). In Hungary - similar to all other EU member states - the organic production-related regulations of the EU apply and are complemented by national rules (Hungarian Ministry of Rural Development, 2013) that can be further diversified by different, and in most cases more stringent, private standards, particularly in the case of trademark use. Therefore, it is of the utmost importance to be aware that the task of inspection is not to test products by laboratory analysis and to consider them organic if they are found to be free of detectable pesticide residues but to ensure that the organic products have been produced according to the relevant legal and procedural regulations through careful and continuous examinations certified by inspection bodies all over the world.

Organic agriculture is inspected in Hungary by two authorized organizations, Biokontroll Hungária Nonprofit Ltd. (HU-ÖKO-01) and Hungária Öko Garancia Ltd. (HU-ÖKO-02). There are no substantial differences in the operations of the two organizations in terms of control and certification, since they both operate under the same legal framework, but the operational scope of the former is significantly larger, corresponding to over $80 \%$ of the certified farmers and holdings.

Historically, organic farming started in Hungary as early as the 1980 s on approximately 1000 ha.
However, the number of organic farming enterprises remained below 100, and the converted area had risen only 10 -fold by 1995 . The first "boom" occurred between 1998 and 2004, when the cultivated area and the number of enterprises rose by 5 -fold to 113000 ha and 4-fold to 1610 enterprises, respectively. After a decade of stagnant yet stable survival of the sector, a second boom started in 2015 mainly as a result of the Rural Development Program discussed above. Since then, the area under organic cultivation and the number of corresponding enterprises has risen to nearly 250000 ha and approximately 4000 enterprises, respectively. Nevertheless, the proportion of ecological agriculture and the share of the organic market were reported to be as low as 1.2\% in 2015 in Bulgaria and less than 1\% in Hungary (Jancsovszka et al., 2015). Currently, organic agriculture accounts for approximately $3 \%$ of the overall arable land (7 $319000 \mathrm{ha}$ ) and $4 \%$ of the utilized agricultural land (5 300000 ha) in Hungary, reflecting a more than 10 -fold increase both in the cultivated area and the number of enterprises since 1998 but remaining substantially below the EU averages (Willer \& Lernoud, 2019; Eurostat, 2020); in the EU, the land under organic agriculture (13 $400000 \mathrm{ha}$ ) corresponds to $7.5 \%$ of the utilized agricultural land (178 000000 ha) (2018 data). In 2018, the proportion of organic agricultural land in the EU was the highest in Austria (24.1\%), and the Visegrad Group countries were led by the Czech Republic (14.8\%), followed by Slovakia (9.9\%), Hungary (3.9\%) and Poland (3.3\%). Current trends indicate a further substantial increase in Hungary, while the overall status of the cultivation area in the EU has remained unchanged since 2017. The overall size of the cultivation areas under organic agriculture in Hungary is shown in Figure 2. Due to the support of the Rural Development Program, the area under inspected organic farming in Hungary (nearly 300000 ha in 2019) and the number of corresponding enterprises (4491 in 2019) rose by $110 \%$ and $214 \%$, respectively, between 2009 and 2019. Data on the organic cultivation areas are rather informative on how 


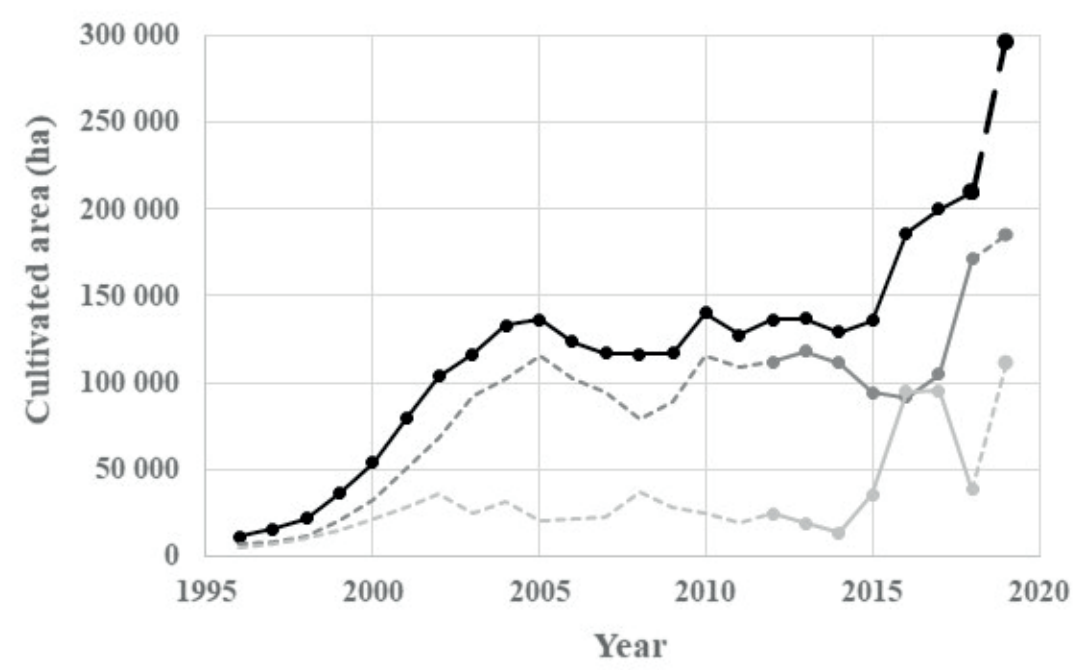

Figure 2. Cultivation area under organic agriculture in Hungary between 1996 and 2019. The inspected area (black line) consists of the area converted to organic agriculture (dark gray line) and the area under the 2-year conversion process (light gray line). The breakdown values before 2012 and the overall values for 2019 are estimations (slashed lines).

direct and strong government support affects the activities in this sector: not only are the two booms (1998-2004 and from 2015 on) clearly visible from the graph, but a sudden drop in the conversion rate in 2018 can also be seen. The size of the areas under conversion dropped from 95 000 ha in 2017 to 38000 ha in 2018. This drop was due to the temporary discontinuation of government subsidies in 2016, to which the organic agriculture division reacted with an immediate halt to the conversion of agrochemical-based cultivation areas to organic farming. However, as the conversion to organic agriculture is subject by law to a 2-year conversion period, the drop in the size of areas under conversion manifested itself only 2 years later, in 2018 . Fortunately, already in 2019, the continuation of government support resulted in an increase in the conversion rate to a slightly higher level (111 000 ha) relative to 2016 and 2017. For the distribution of land under organic agriculture in the Visegrad Group countries, the proportion of arable land (in contrast to permanent grassland and permanent crops) is the highest in Poland (73.4\%), followed by Hungary (39.9\%), Slovakia (34.2\%) and the Czech Republic (15.2\%). As a comparison, the corresponding ratio in Austria
(37.3\%) fell between those in Hungary and Slovakia. Over half $(55.5 \%)$ of the organically cultivated areas were meadows, pastures, and extensive grasslands; over one-third (35.3\%) of the areas were cultivated in arable farming; and perennials/fruits, vegetables and fallow land represented the cultivation in $5.1 \%, 1.8 \%$ and $2.3 \%$ of the areas, respectively.

\section{Agroecology support through the BIOEAST initiative}

To establish a common regional strategic framework for research and innovation on the development of sustainable biomass-based systems (strategies) for the countries in Central and Eastern Europe, a transnational initiative was officially proposed by Hungary in 2014 at the European Innovation Partnership for Agricultural Productivity and Sustainability (EIP-AGRI) Conference held in Budapest, followed by the official launch of the regional cooperation program BIOEAST by the Visegrad Group countries (the Czech Republic, Hungary, Poland and Slovakia) in 2016 (Juhász \& Vásáry, 2017). Romania, Bulgaria, Slovenia, Estonia, Croatia, Latvia and Lithuania joined the 
initiative, which reached 11 member countries in 2018. Among its objectives, BIOEAST pursues research and innovation, rural development and other policies towards bioeconomic development in Central and Eastern Europe by the creation of a favorable intersectoral framework for the sustainable deployment of biomass potential. A pronounced regional aim of the initiative is to support vulnerable rural communities that are less able to adapt to economic insecurity and climate change risks. Within the five macroregion-level thematic areas, agroecology is coordinated within BIOEAST by Hungary, and the tasks related to supporting the vulnerable rural communities are divided between the scientific discipline, social movement and practice aspects (Wezel et al., 2009) of agroecology. The EU Common Agricultural Policy and the Horizon Europe 2021-2027 program place great emphasis on supporting environmentally friendly production methods, such as agroecology, through the effective adaptation to the effects of climate change (the cultivation of resilience in farmers and rural communities, the diversification of agro-ecosystems, the development of agro-forestry systems, the conservation of water, and the development of soil health and agrobiological diversity) and through the increased efficiency and quality of agriculture and food systems. Moreover, recognizing the urgent needs to reduce dependency on pesticides and antimicrobials, to reduce the use of excess fertilization, to improve animal welfare, and to reverse biodiversity loss, the European Green Deal set goals to reduce pesticide use in the EU by $50 \%$ by 2030 , to enhance provisions on integrated pest management, to increase the share of organic farming to $30 \%$, and to promote greater use of safe alternatives (e.g., biologically active substances). BIOEAST subsequently identified thematic areas including (1) soil health, (2) transition to agriculture without chemical pesticides, (3) genetic resources and agricultural diversification, (4) animal health and welfare, (5) local food systems and rural development, and (6) innovation, smart farming and knowledge sharing. Reflection groups within the BIOEAST initiative are currently working on developing a strategic research and innovation agenda of common intentions in Central and Eastern Europe based on national inputs.

\section{External environmental factors jeopardizing agroecology}

Monoculture-based intensive agricultural technologies, through their continuous pressure on biodiversity, present the main threat to agroecosystems. Nonetheless, biodiverse cultivation areas established among monocultures may create substantial habitat reservoirs or refuges for species at risk unless the surrounding intensive pesticide use precludes the formation of healthy food chains at these spots. Agroecology, including organic agriculture, offers crop cultivation without synthetic pesticides (and their metabolites) or genetically modified organisms (GMOs), yet such qualified status may be jeopardized by agro-environmental conditions (Székács, 2013). The wide occurrence of persistent pesticide residues in soil and water basin sediments of water-soluble or leaching pesticide residues in surface water may corrupt produce quality through microcontaminant adsorption during crop cultivation or through irrigation with contaminated surface water.

\section{Extensive pesticide contamination}

In systematic surveys comparing regional pesticide contamination in intensive and organic agricultural cultivation sites in Hungary from 1990 on, surface water samples from agrochemicalbased agricultural fields were often found to be contaminated with pesticide residues, most commonly with herbicides used in maize production. Surface water samples collected near organic farming areas between 2006 and 2008 were not found to be pesticide-free either, but the residue levels were typically found to be lower than those in intensively cultivated areas. At that time, the main pesticide pollutants in surface 
water, probably due to drift from neighboring intensively cultivated fields, were atrazine (banned in the EU since 2004) $\left(<250 \mathrm{ng} \mathrm{L}^{-1}\right)$, trifluralin (banned in the EU since 2008) $(<50$ $\mathrm{ng} \mathrm{L^{-1 }}$ ), diazinon (banned in the EU since 2011) $\left(<50 \mathrm{ng} \mathrm{L}^{-1}\right)$, acetochlor (phased out in the EU since 2011), metolachlor (currently registered in the EU solely in the form of its purified $S$ enantiomer under the name of $S$-metolachlor) $\left(<20 \mathrm{ng} \mathrm{L}^{-1}\right)$ and lindane (banned in the EU since 2000) $\left(<15 \mathrm{ng} \mathrm{L}^{-1}\right)$; the main pesticide pollutants in soil were DDE (a metabolite of DDT banned in Hungary since 1968), lindane and trifluralin (Székács, Mörtl \& Darvas, 2015). The results indicated that organic agriculture can still be subject to low but existing pesticide exposure, possibly from surface and irrigation water, as well as persistent soil pesticide contaminants. The assessment of the possible local and regional roles of such residues and their potential effects on food safety requires systematic monitoring of these contaminants in environmental matrices.

A recent pesticide toxicology-related issue corresponds to health benefits attributed to produce or food from organic production. The substantially decreased pesticide exposure of consumers of organic produce relative to consumers of produce of intensive agriculture and health benefits in the former consumer group have been proven, but that those health advantages originated from the decreased pesticide residue exposure due to consumption of food products from organic agriculture has not been proven (Mesnage et al., 2020). Instead, health and environmental consciousness in the behavioral attitude of this consumer group are considered the causative factors of the health benefits.

\section{Hygienic application of biocides}

Environmental or urban applications of biocides may affect neighboring agricultural fields. This is of particular importance for organic agriculture, as biocide substances used, e.g., for mosquito control, may be identical to synthetic agricultural insecticide active ingredients. Over the decades, typical anti-insect agents (used both as agricultural insecticides and biocides in hygienic applications) have included, until the banning of some, malathion (2A category carcinogen probably carcinogenic to humans and banned in the EU since 2006), dichlorvos (2B category carcinogen possibly carcinogenic to humans and banned in the EU since 2006), deltamethrin and Bacillus thuringiensis israelensis endotoxin. It is a regulatory anomaly that these substances are (or used to be) legally regulated differently if used as pesticides or biocides (Németh \& Székács, 2012).

\section{Genetically modified (GM) crops}

The coexistence of organic agriculture and the cultivation of GM crops appears to be practically impossible in countries of relatively small territory (e.g., European countries, including Hungary) due to hybrid formation by cross-pollination affecting produce quality already in the year of cultivation, as indicated in our experiments with insect-resistant GM crops (MON 810) (Székács \& Darvas, 2012; Székács, 2020) with up to 35\% unintended transgene expression.

\section{Natural organic microcontaminants}

While pesticide occurrence is demonstrably and substantially lower (optimally none) in organic agriculture, the occurrence of other organic microcontaminants of agricultural origin, e.g., mycotoxins, can be considerable. Nonetheless, the toxicological significance of mycotoxin levels in organic produce is often overestimated. Mycotoxin contamination appears to be a minor problem in the EU in organic produce: a recent survey of the EU Rapid Alert System for Food and Feed indicated only a $0.2 \%$ incidence of mycotoxin-related cases in organic food in an 8 year sampling regime (Maczák et 
al., 2011). This rate is similar or even somewhat better than that seen for produce or food products from agrochemical-based agricultural production (Parisi, Barone \& Sharma, 2016; Pigłowski, 2019).

\section{Utilization rate of fossil fuel}

Additionally, a key element in assessing the true sustainability of organic agricultural practices is the application rate of fossil fuel. Organic production technologies are alleged to use more diesel per unit of production than agrochemical-based, intensive agriculture technologies, partly due to mechanical protection (plowing, weed combing, shallow cultivation, weed scorching) against weeds (Woods et al., 2010). This is balanced, however, by the improved energy efficacy in the organic sector (Lynch, MacRae \& Martin, 2011; Gomiero, Pimentel \& Paoletti, 2011) with reduced fossil energy inputs but often increased human energy inputs (Woods et al., 2010). The higher energy efficacy is often offset by lower achievable yields, and with uncertainties and under different sets of assumptions, the overall balance is positive (El-Hage Scialabba \& M. Müller-Lindenlauf, 2010; Gomiero, Pimentel \& Paoletti, 2011; Smith, Williams \& Pearce, 2014) or negative (Searchinger et al., 2018; Smith et al., 2019). Even with a positive balance, the environmental costs (mostly unknown) of converting natural ecosystems to agroecosystems to meet the global food demand must be considered (Lorenz \& Lal, 2016).

\section{Agroecology research projects}

Targeted research focused on sustainable agriculture began in Hungary in the early 1980s and came to fruition with the official introduction of organic farming. Projects continued to be commenced in support of organic agriculture and agricultural ecology, but the first official research program with the declared term of agroecology was started in 2002, and projects on the environmental, ecological, technological, educational and societal aspects have continued during the last two decades (Table 1.)

\section{Project Agroecology (2002-2005)}

This project, sponsored by the Hungarian National Research and Development Program (OM-3B/0057/2002), aimed to map the environmental interrelationships of agroecosystems and the possibilities of their control in Hungary. In the framework of the project, the consortium undertook the task of establishing the basis of a comprehensive agroecological concept by elaborating an up-to-date synthesis of agroecology-focused topics, including soil science, water regime, agrometeorology, crop production, plant protection, and biodiversity, and the regional research that involved the assessment of the elements of agroecosystems and their interrelationships; the description, characterization and quantification of the environmental effects of different agroecosystems; the evaluation of the mass and energy transport processes in agroecosystems; and the soil-water-near surface atmosphere-plant system (Várallyay, 2004; Székács et al., 2004).

\section{Project GAK II POP on Soil and Water Contaminating Pesticides (2006-2008)}

This "fundamental research" project for the feasibility of ecological agriculture, funded by the National Technology Development Committee (OMFB-00947-00949/2005) in Hungary, was carried out between 2006 and 2008 by a consortium of the Plant Protection Institute of the Hungarian Academy of Sciences, Biokontroll Hungária Nonprofit Ltd. and Bio-Kalibra Bt. Organic production standards do not allow the use of synthetic pesticides. However, cultivation plots and fields, not only in intensive agriculture but also in organic farming or agroecology, can 
Table 1. Selected research and training projects in Hungary since 2002 related to organic agriculture and agroecology.

\begin{tabular}{|c|c|c|c|}
\hline Project & Duration & Partner countries & Focus and features \\
\hline Agroecology & $2002-2005$ & Hungary (domestic) & $\begin{array}{l}\text { Agroecology possibilities in Hungary } \\
\text { Environmental interrelationships (soil science, water regime, } \\
\text { agrometeorological, crop production, plant protection, } \\
\text { biodiversity) of agroecosystems and the possibilities of their } \\
\text { control. }\end{array}$ \\
\hline GAK II POP & 2006-2008 & Hungary (domestic) & $\begin{array}{l}\text { Persistent pesticide residues occurring in organic } \\
\text { agriculture } \\
\text { The analysis of soil- and water- contaminating pesticides } \\
\text { in organic agriculture. The identification of the threat of } \\
\text { persistent soil pollutants and of contamination through } \\
\text { irrigation water. }\end{array}$ \\
\hline Ecologica & $2005-2007$ & $\begin{array}{l}\text { The Czech Republic, Estonia, } \\
\text { Hungary, Latvia, Romania, } \\
\text { Slovakia, and Slovenia }\end{array}$ & $\begin{array}{l}\text { Training for organic agriculture } \\
\text { The establishment of a European-level central educational } \\
\text { database for consultants in organic farming. }\end{array}$ \\
\hline $\begin{array}{l}\text { Green Plant } \\
\text { Protection }\end{array}$ & 2009-2011 & Hungary, Italy, and Slovakia & $\begin{array}{l}\text { Development of mobile learning tools for plant protection } \\
\text { Interactive web- and mobile phone-based learning platforms } \\
\text { on organic agriculture and nonchemical plant protection in } \\
\text { the central-eastern European region. }\end{array}$ \\
\hline Sagiter & 2013-2016 & $\begin{array}{l}\text { Belgium, France, Germany, } \\
\text { Hungary, Romania, Slovenia, } \\
\text { and Spain }\end{array}$ & $\begin{array}{l}\text { Training itineraries for trainers } \\
\text { The development and application of tools, methods and } \\
\text { events that could be used to communicate and disseminate } \\
\text { agroecological knowledge and practical experience. }\end{array}$ \\
\hline SoFarEDU & 2017-2020 & $\begin{array}{l}\text { Austria, the Czech Republic, } \\
\text { Germany, Hungary, and Norway }\end{array}$ & $\begin{array}{l}\text { Social farming in higher education } \\
\text { The use of agricultural enterprises as a setting for therapy, } \\
\text { integration, rehabilitation or occupation of people with } \\
\text { special needs. }\end{array}$ \\
\hline Revitalist & 2017-2020 & $\begin{array}{l}\text { The Czech Republic, Hungary, } \\
\text { Italy, and the United Kingdom }\end{array}$ & $\begin{array}{l}\text { Social farming } \\
\text { A social farm mentor training program using the Practical } \\
\text { Skills Therapeutic Education program. }\end{array}$ \\
\hline Uniseco & 2018-2021 & $\begin{array}{l}\text { Austria, the Czech Republic, } \\
\text { Finland, France, Germany, } \\
\text { Greece, Hungary, Italy, Latvia, } \\
\text { Lithuania, Romania, Spain, } \\
\text { Sweden, Switzerland, and the } \\
\text { United Kingdom }\end{array}$ & $\begin{array}{l}\text { Understanding and improving the sustainability of } \\
\text { agroecological farming systems } \\
\text { The development of innovative approaches to enhance } \\
\text { the understanding of socioeconomic and policy drivers } \\
\text { and barriers to further development and implementation } \\
\text { of agroecological practices in EU farming systems. } \\
\text { Strengthening sustainability through co-constructing } \\
\text { strategies and incentives for the promotion of improved } \\
\text { agroecological approaches. }\end{array}$ \\
\hline trAEce & 2019-2022 & $\begin{array}{l}\text { Austria, the Czech Republic, } \\
\text { Hungary, Portugal, and Romania }\end{array}$ & $\begin{array}{l}\text { Vocational training for farmers } \\
\text { The provision of training tools for farmers and trainers to } \\
\text { assist them in integrating agroecological principles into their } \\
\text { agricultural practices. }\end{array}$ \\
\hline TopPlant & 2020-2022 & $\begin{array}{l}\text { Austria, Croatia, Hungary, and } \\
\text { Slovenia }\end{array}$ & $\begin{array}{l}\text { Vocational education and training in organic agriculture } \\
\text { The development of curricula, guidelines and training } \\
\text { materials in an interactive e-learning tool on organic/ } \\
\text { biological plant protection. }\end{array}$ \\
\hline
\end{tabular}

have very diverse histories and residues due to the previous use of persistent pesticides, which is a real threat to organic farming. These pesticides can be found in various layers of the soil, and certain plants can uptake and therefore, mobilize them. As a result, certain crops cultivated under organic conditions can reach the market containing residues. A similar problem may come from irrigation water (Maloschik et al., 2007). The project aimed to improve the quality of the irrigation water and the soil testing methods for organic farming to guarantee crop safety. A further 
objective of the project aimed to identify risky plants and to prepare bioremediation work plans.

\section{Projects Ecologica (2005-2007) and Green Plant Protection (2009-2011)}

Within the scope of the Leonardo da Vinci Program of the EU Education, Audiovisual and Culture Executive Agency, pilot project Ecologica (the development of a central data bank at the European level for the education of organic farming advisers, HU 05/B/F/PP-170018) developed a central data bank (Ecolibrary) of various digital resources categorized into 14 modules (organic farming, EU and national cultural knowledge, multifunctionality of an organic farm, conversion to organic farming, control and certification of organic farms, advisory knowledge, plant production and animal husbandry, etc.) designed for the education of agroecology advisers. The project involved partners from 8 European countries, was coordinated by Corvinus University of Budapest, and had the active participation of Biokontroll Hungária Nonprofit Ltd.; it created a Europeanlevel central educational database for consultants on organic farming, enabled advisers to gain full comprehension of the organic agricultural system, and provided a broad overview of various aspects of organic farming issues and the basics of organic farming, including field crop production in organic farming, organic fruit and vegetable growing, soil production, tillage, green manure and composting.

The subsequent project Green Plant Protection (GPP) (the utilization of advances of ICT developments in mobile learning to promote interactive learning for adult people in the field of organic agriculture, 2009-1-SK1-LEO-05-00792) developed interactive web- and mobile phone-based learning platforms focused on plant protection (from animal pests, plant pathogens and cropland weeds) in the central-eastern European region (Slovakia, Hungary), with special emphasis on the active access to lifelong learning in the field of organic agriculture and nonchemical plant protection. The project was coordinated by the Slovak University of Agricultural Sciences in Nitra, and the consortium members included Biocert Italia srl. (a nonprofit scientific and technical organization dedicated to the development of agro-environmental management) in Italy and the Hungarian Association for Organic Farming. The training materials were prepared in the Slovakian, Hungarian, Italian and English languages.

\section{Project Sagiter (2013-2016)}

The Agroecological Knowledge and Ingenuity of Terroirs project (the Leonardo da Vinci Development of Innovation European program 538785-LLP-1-2013-1-FR-LEONARDO-LMP) (https://sagiter.eu/wakka.php) focused on progress towards sustainable agriculture education by combining both scientific and nonspecialized informal knowledge resulting from everyday experiences. Eleven institutions from 7 European countries (France, Germany, Spain, Belgium, Slovenia, Romania and Hungary) worked together to promote agroecological knowledge and the innovative systems that are implemented in the territories. The project's collection of practical experiences, educational methods and tools, bibliographical resources and sample training sessions supports educators in covering the complexity of sustainable agriculture in education.

\section{Projects SoFarEDU (2017-2020) and Revitalist (2017-2020)}

Although this paper does not focus in-depth on the social aspects of agroecology, it is still worth highlighting projects that facilitate the public transition to the agroecology concept and articulate policy-making towards agroecology. The social integration of disadvantaged groups presents a complex challenge at the national and international levels across Europe and globally. 
There is a pressing need for the advancement of knowledge about social farming that uses an agricultural enterprise as a setting for therapy, integration, rehabilitation or meaningful occupation of people with special needs. For the farmer, it represents an opportunity to diversify income and labor sources and to exercise social responsibility. Social farming relates to a complex reframing of agricultural and rural areas to provide socially and environmentally sustainable models in comparison to what is present within the dominant agribusiness model. The Social Farming in Higher Education Erasmus+ strategic partnership project SoFarEDU (2017-1-DE01KA203-003583) (https://sofaredu.eu), similar to the social farm mentor training project Revitalist (2017-1-HU01-KA202-035932) (http://www.revitalist.eu), intends to take further the concept of social farming in Hungary by empowering rural communities and rural economies across Europe through increasing the quantity and, above all, the quality of social farms. The SoFarEDU project team (Germany, Austria, the Czech Republic, Norway and Hungary) elaborated a new social farm training curriculum in higher education to provide universities with tools to teach the necessary social farming skills (Nobelmann et al., 2020). The project Revitalist, based on a social and therapeutic method of education (Practical Skills Therapeutic Education, PSTE), elaborated a vocational training curriculum for social farm mentors by creating and collecting a pool of background materials and by establishing a network of professionals and responding to several European regional and local policy needs. The target groups of the new social farming mentor training curriculum are social farm employees and social and agricultural professionals. The project partners are from Hungary, the United Kingdom, the Czech Republic and Italy.

\section{Project Uniseco (2018-2021)}

Project UNISECO (Understanding and Improving the Sustainability of Agro-Ecological Farming
Systems in the EU, SFS-29-2017 Grant agreement 773901) (https://uniseco-project.eu), funded by the EU H2020 research and innovation program, aims to develop innovative approaches to enhance the understanding of socioeconomic and policy drivers and barriers for further development and the implementation of agroecological practices in EU farming systems. The aim and overarching objective of the project is to strengthen the sustainability of European farming systems through co-constructing improved and practice-validated strategies and incentives for the promotion of improved agroecological approaches and agroecological farming systems (AEFS) in participatory case studies in 15 European countries (Austria, Belgium, the Czech Republic, Finland, France, Germany, Greece, Hungary, Italy, Latvia, Lithuania, Spain, Sweden, Switzerland, and the United Kingdom). The case studies follow the developed adapted socioecological system framework (Guisepelli et al., 2018) to undertake in-depth analyses of the underlying processes (using interviews, focus group discussions and workshops with key actors) and quantitative assessments of the sustainability implications of innovative approaches, market incentives and policy instruments for AEFS (using the decision support tools SMART, Cool Farm Tool and COMPAS). The case studies aim to answer the following questions: (a) How can barriers and the dilemma of AEFS be addressed in a specific case study context? (b) What are the socioeconomic and environmental implications of the transition to agroecological farming? (c) Why were innovative strategies and incentives successful (or unsuccessful) in enhancing the joint provision of private and public goods of AEFS in a specific case study context? (d) What lessons can be learned for other cases and future policies?

The UNISECO case study in Hungary focuses on taking steps towards sustainable natural resource management to increase economic viability in mid-sized arable grain-protein-oil cropping farms. The specific sustainability challenge is how to integrate agroecological practices on arable land in highly market-oriented arable farming systems 
to maintain and improve soil quality without significant negative impacts on the economic viability of the farms.

\section{Project trAEce (2019-2022)}

Project trAEce (the Agroecological Vocational Training for Farmers program within the EU Erasmus+ Program 2019-1-HU01-KA202-060895) (https://traece.eu) started in September 2019 and will run for 3 years to provide training tools to farmers and trainers, which will assist them in integrating agroecological principles into their agricultural practices. It is a new initiative that intends to advance the concept of agroecology as both a discipline and a practice by pooling together the experience and expertise of 6 prominent institutions from 5 European countries (Hungary, Romania, Austria, the Czech Republic and Portugal). The project partners will develop a country-specific situation analysis that will contribute to gaining a comprehensive view of the level of knowledge and opinion of farmers regarding agroecology-based activities, as well as identifying related political discourses, regulations, actors, practices, networks, etc. Based on the situation analysis, an agroecology vocational training program will be developed by the project team. The 6-module training program will outline topics that will help farmers design or transform their farms in line with agroecology principles and strive for social and environmental sustainability while improving the profitability of their agricultural activities.

\section{Project TopPlant (2020-2022)}

Project TopPlant (the Trainers for Plant Protection in Organic Farming program within the EU Erasmus+ Program 2020-1-AT01-KA202-078107) aims to develop new and innovative training on organic plant protection for farmers who have already started organic farming or who plan to do so and to train trainers concerning the new vocational education and training (VET) program to enable them to be able to train the target group of farmers. The four intellectual outputs of the project are a methodological curriculum on organic plant protection, a training manual for organic plant protection trainers, crop-specific guidelines for organic plant protection, and an interactive e-learning tool. The training will take methodological principles of organic farming into consideration, as well as practical guidelines on how to deal with the organic protection of certain crops. In addition to the curriculum itself, a training manual will be developed that will be used by the VET providers in training the target group, as well as crop-specific guidelines that will elaborate the organic protection of certain crops in the project countries of Austria, Croatia, Hungary and Slovenia. To make the training available to a large number of farmers, an interactive e-learning tool will also be developed, which will enable the farmers to access the training via computers, tablets or smartphones.

\section{Involvement in the international advancement of agroecology}

Hungary, through its permanent delegations, has participated in all agroecology-focused events organized by the Food and Agriculture Organization (FAO) of the United Nations (UN), including two main global symposia in Rome (in 2014 and 2018), and hosted the European Symposium in 2016. While the working documents of certain regional symposia (Mexico City, 2015; Abidjan, 2016; Bangkok, 2016; Kunming, 2016; La Paz, 2016) captured the political movement aspect of agroecology, the summary statement after the European Symposium (Budapest, 2016) emphasized the environmental and ecological scientific aspects, including the recycling of biomass, circular food production systems, soil health and conservation, the optimization of natural assets (solar energy, air, water and nutrients), loss minimization, the conservation of biological and genetic biodiversity, and the exploitation of biological interactions 
in the agroecosystem. Additionally, local value chains, locally available assets and knowledge, and societally accepted innovations have also been emphasized to achieve a sustainable transition to agroecology. The concept has been included in the working schedule of the FAO Committee on World Food Security (CFS), where a new study summarizing the vocational-scientific achievements in agroecology has been compiled (HLPE, 2019); comments by the Hungarian delegation on the economic, environmental and societal dimensions of agroecology have been officially sent to the committee, and the comments have been in majority considered in the final document, to be followed by a subsequent policy convergence process.

\section{Conclusions}

Ecology research on plant protection has emerged in Hungary, which holds a pioneering role worldwide, and organic farming also appeared early within the region. Unfortunately, the attainment of this prominent position has not been followed by a growth of organic agriculture as rapid as in other regions of the EU. Based upon antecedents in research on sustainable agriculture, scientific research projects on agroecology also started intensively in Hungary relatively early within the region, in 2002. Agroecology-related projects covering the environmental, ecological, technological, educational and societal aspects of agroecology are embedded in international research efforts. Since 2016, Hungary has played a prominent role in Central and Eastern Europe in proposing and advancing the transnational initiative BIOEAST by the Visegrad Group countries (the Czech Republic, Hungary, Poland and Slovakia), within which the thematic area of agroecology is being coordinated by Hungary with a pronounced regional aim of supporting vulnerable rural communities that are less able to adapt to economic insecurity and climate change risks. Additional targets include the diversification of agro-ecosystems, agro-forestry, environmental quality (surface water, soil), agro- biological diversity, and according to the objectives of the European Green Deal, the growth of organic farming and the reduction of pesticide use.

\section{Acknowledgments}

The authors thank Lyndre Nel for her constructive criticism and proofreading of the paper.

This manuscript summarizes the authors' intended contribution at the Workshop on Challenges for Agroecology Development for the Building of Sustainable Agri-Food Systems (CRP), which was due to take place at the Faculty of Agricultural Sciences, University of Chile, Santiago de Chile, on 11-13 November 2019 and which was sponsored by the OECD Cooperative Research Programme: Biological Resource Management for Sustainable Agricultural Systems. Although due to the circumstances the workshop did not take place as a physical meeting, the contributions intended to be supported by the OECD CRP are published in this Thematic Issue.

The work reported was supported by projects trAEce (2019-1-HU01-KA202-060895) and TopPlant (2020-1-AT01-KA202-078107) under the European Union's Erasmus+ program.

\section{Disclaimer}

The opinions expressed and arguments employed in this manuscript are the sole responsibility of the authors and do not necessarily reflect those of the OECD or of the governments of its Member countries. The European Commission's support for the production of this publication does not constitute an endorsement of the contents, which reflect the views only of the authors, and the Commission cannot be held responsible for any use which may be made of the information contained therein.

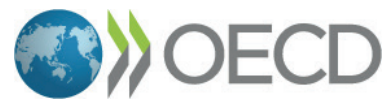




\title{
Resumen
}

\begin{abstract}
A. Székács, P. Roszík, K. Balázs, L. Podmaniczky, y A. Ujj. 2020. Iniciativas de agroecología en Hungría y la región de Europa Central. Int. J. Agric. Nat. Resour. 216-234. Las iniciativas de agroecología, en respuesta a los problemas ambientales y ecológicos de la tecnología agrícola intensiva basada en agroquímicos, comenzaron en Hungría en la década de 1980, primero en la región de Europa Central y Oriental. El sector creció sustancialmente desde entonces, y actualmente enfrenta su segundo auge, pero sigue siendo sustancialmente inferior al nivel promedio en la Unión Europea (UE) o en los Países del Grupo Visegrad (República Checa, Hungría, Polonia y Eslovaquia). Esta revisión resume los desarrollos tempranos y recientes en Hungría en el contexto de la región, principalmente en relación con la investigación científica y los aspectos políticos. El crecimiento 10 veces mayor del sector de la agricultura ecológica en dos décadas brinda la esperanza de alcanzar un nivel más cercano al promedio de la UE, y se discute en relación con el entorno legal regulador, el Programa de Desarrollo Rural armonizado de la UE. Además, el Acuerdo Verde Europeo prevé reducir el uso de pesticidas en un 50\% para 2030 y apoyar la agroecología para reducir el exceso de fertilización, aumentar la agricultura ecológica y revertir la pérdida de biodiversidad. Hungría persigue estos objetivos a fondo, entre otros, la iniciativa transnacional BIOEAST. Los riesgos ambientales que ponen en peligro la agroecología se resumen en un contexto sistemático, que abarca no solo los microcontaminantes orgánicos agrícolas, sino también los productos de biotecnología agrícola y los problemas de eficacia de la utilización de energía. Se describe en los proyectos de investigación anteriores y actuales relacionados, así como la participación en el avance internacional de la agroecología.
\end{abstract}

Palabras clave: Investigación, política, Programa de Desarrollo Rural, proyecto, riesgos.

\section{References}

Altieri, M.A. (2018). Agroecology: The Science of Sustainable Agriculture. CRC Press, Boca Raton, USA.

Ángyán, J., Balázs, K., Podmaniczky, L., \& Skutai, J. (2003). Integrated land use zonation system in Hungary as a territorial base for agri-environmental programs. In: Helming, K. \& Wiggering, H. (Ed.), Sustainable Development of Multifunctional Landscapes. Springer-Verlag, Heidelberg, Germany, pp. 125-141. doi: 10.1007/978-3-66205240-2_9

Ángyán, J., Czene, Zs., \& Tátrai, E. (Ed.). (2012). The Ignác Darányi Plan. Execution Frame Plan of the National Rural Development Strategy (NVS 20122020) [in Hungarian]. Ministry of Rural Development, Hungary. Retrieved from https://2010-2014. kormany.hu/download/3/70/70000/DIT kiadvany_210x148mm_LEAD_kifut_nelkul.pdf
Balogh, J. (1946). The structure of biocenoses. [in Hungarian] Állattani Közlemények, 43:1-14.

Darvas, B., Polgár, L.A., Schwarczinger, I., \& Turóczi. Gy. (1999). Biological plant protection and its status in Hungary. [in Hungarian] OMFB, Budapest, Hungary

De Wit, J., \& Verhoog, H. (2007). Organic values and the conventionalization of organic agriculture. NJAS-Wageningen Journal of Life Sciences, 54: 449-462.

Dvořáková Líšková, Z., Klufová, R., \& Rost, M. (2019). Ex-post evaluation of local action groups in LEADER Programmes. Deturope, 11(1):4-20. Retrieved from http://www.deturope.eu/img/upload/content_85229208.pdf

EC (European Council). (2007). Council Regulation (EC) No 834/2007 of 28 June 2007 on organic production and labelling of organic products and repealing Regulation (EEC) No 2092/91. Official Journal of the European Union L 189:1-23. 
Retrieved from https://eur-lex.europa.eu/legalcontent/EN/TXT/PDF/?uri=CELEX:32007R083 $4 \&$ from $=\mathrm{EN}$

EC (European Commission). (2008a). Commission Regulation (EC) No 889/2008 of 5 September 2008 laying down detailed rules for the implementation of Council Regulation (EC) No $834 / 2007$ on organic production and labelling of organic products with regard to organic production, labelling and control. Official Journal of the European Union L 250:1-84. Retrieved from https://eur-lex.europa.eu/legal-content/EN/TXT/ PDF/?uri=CELEX:32008R0889\& from=EN

EC (European Commission). (2008b). Commission Regulation (EC) No 1235/2008 of 8 December 2008 laying down detailed rules for implementation of Council Regulation (EC) No 834/2007 as regards the arrangements for imports of organic products from third countries. Official Journal of the European Union L 334:25-52. Retrieved from https://eur-lex.europa.eu/legal-content/EN/TXT/ $\mathrm{PDF} /$ ?uri=CELEX:32008R1235\&from=EN

El-Hage Scialabba, N., \& Müller-Lindenlauf, M. (2010). Organic agriculture and climate change. Renewable Agriculture and Food Systems 25(2):158-169. doi: 10.1017/ S1742170510000116

EP (European Parliament and Council). (2013). Regulation (EU) No 1306/2013 of the European Parliament and of the Council of 17 December 2013 on the financing, management and monitoring of the Common Agricultural Policy and repealing Council Regulations (EEC) No 352/78, (EC) No 165/94, (EC) No 2799/98, (EC) No 814/2000, (EC) No 1290/2005 and (EC) No 485/2008. Official Journal of the European Union L 347:594-607. Retrieved from https://eur-lex.europa.eu/legal-content/EN/TXT/ PDF/?uri=CELEX:32013R1306

Eurostat. (2020). Organic farming statistics. Eurostat Press Office. Retrieved from https://ec.europa. eu/eurostat/web/products-eurostat-news/-/DDN20190130-1

Fieldsend, A.F., Tudor, M.-M., Varga, E., Florian, V., Rusu, M., Biró, Sz., Chiritescu, V., \& Kruszlicika, M. (2017). Innovation in farming and rural areas in Hungary and Romania: its current state and determining factors. Rural Areas and Development 14:325-339. doi: 10.22004/ ag.econ. 273087

Gallardo-López, F., Hernández-Chontal, M.A., Cisneros-Saguilán, P., \& Linares-Gabriel, A. (2018). Development of the concept of agroecology in Europe: A review. Sustainability, 10:1210. doi: 10.3390/su10041210

Gomiero, T., Pimentel, D., \& Paoletti, M.G. (2011). Environmental impact of different agricultural management practices: conventional vs. organic agriculture. Critical Reviews in Plant Sciences, 30:95-124. doi: 10.1080/07352689.2011.554355

Guisepelli, E., Fleury, P., Vincent, A., Aalders, I., \& Vanni, F. (2018). Adapted SES Framework for AEFS and Guidelines for Assessing Sustainability of Agricultural Systems in Europe. Deliverable Report D2.1, UNISECO Project. Retrieved from https://uniseco-project.eu/assets/content/ resources/02-deliverables/UNISECO D2.1 Adapted SES Framework for AEFS and Guidelines for Assessing Sustainability of Agricultural Systems in Europe-publication final.pdf

HLPE (High Level Panel of Experts on Food Security and Nutrition). (2019). Agroecological and other innovative approaches for sustainable agriculture and food systems that enhance food security and nutrition. A report by the High Level Panel of Experts on Food Security and Nutrition. HLPE of the Committee on World Food Security, FAO, Rome, Italy. Retrieved from http://www. fao.org/3/ca5602en/ca5602en.pdf

Hungarian Ministry of Agriculture and Rural Development. (2009a). Decree No. 61 of 2009 (V. 14.) FVM of the Ministry of Agriculture and Rural Development laying down the conditions of support for agricultural environmental management from the European Agricultural Fund for Rural Development. Retrieved from http:// www.fao.org/faolex/results/details/en/c/LEXFAOC 124000

Hungarian Ministry of Agriculture and Rural Development. (2009b). Decree No. 77 of 2009 (VI. 30.) FVM of the Ministry of Agriculture and Rural Development on the modification of Decree 
No. 61 of 2009 (V. 14.) laying down the conditions of support for agricultural environmental management from the European Agricultural Fund for Rural Development.

Hungarian Ministry of Rural Development. (2013). Decree No. 34 of 2013 (V. 14.) VM of the Ministry of Rural Development concerning the procedure of certification, production, marketing, labeling and control of agricultural products and food deriving from organic agriculture. Retrieved from http://www.fao.org/faolex/results/ details/en/c/LEX-FAOC124497

Jancsovszka, P., Mészáros, D., Sipos, B., \& Szalai, T. (2015). Organic sector in Bulgaria and Hungary: a review. Hungarian Agricultural Research, 24(3):24-29. Retrieved from http://www.agrarlapok.hu/sites/default/files/har_2015_03.pdf

Jermy, T. (1956). Zönologie und angewandte Entomologie. Tagungsberichte/Deutsche Akademie der Landwirtschaftswisenschaften zu Berlin. Vol. 5. Kongressbericht der Pflanzenschutzkongress (Berlin, 11 bis 16 Juli 1955), pp. 39-46. Retrieved from https://books.google.hu/books/ about/Pflanzenschutz_Kongress_Berlin_11_ bis_16.html?id=ed4nzQEACAAJ

Juhász, A., \& Vásáry, V. (2017). BioEast: CentralEastern European initiative for knowledge-based agriculture, aquaculture and forestry in the bioeconomy. Rural Areas and Development, 14:7591. doi: 10.22004/ag.econ.272183

Kulcsár, L., Ónodi, G., Ángyán, J., \& Podmaniczky, L. (1995). Rural Development in Hungary. National Report. OECD, Paris, France.

Lorenz, K., \& Lal, R. (2016). Environmental impact of organic agriculture. Advances in Agronomy 139:99-152. doi: 10.1016/bs.agron.2016.05.003

Lynch, D.H., MacRae, R., \& Martin, R.C. (2011). The carbon and global warming potential impacts of organic farming: Does it have a significant role in an energy constrained world? Sustainability, 3(2):322-362. doi: 10.3390/su3020322

Maczák, B., Mészáros, L., Szerleticsné Túri, M., \& Szeitzné Szabó, M. (2011). Analysis of food safety aspects of organic food based on published official European Union information. [in Hungarian] Biokontroll, 2(3):4-11. Retrieved from http://www.ecotox.hu/ecotox 2/biocontrol/ nr/004/biokontroll_04.pdf

Maloschik, E., Ernst, A., Hegedüs, Gy., Darvas, B., \& Székács, A. (2007). Monitoring water-polluting pesticides in Hungary. Microchemical Journal, 85:88-97. doi: 10.1016/j.microc.2006.05.002

Maynard, J., \& Vida, G. (Ed.). (1990). Organizational Constraints on the Dynamics of Evolution. Manchester University Press, Manchester, UK

Mesnage, R., Tsakiris, I.N., Antoniou, M., \& Tsakiris, A. (2020). Limitations in the evidential basis supporting health benefits from a decreased exposure to pesticides through organic food consumption. Current Opinion in Toxicology, 19:50-55. doi: 10.1016/j.cotox.2019.11.003

Moudrý, J., Bernas, J., Moudrý, J., Konvalina, P., Ujj, A., Manolov, I., Stoeva, A., Rembialkowska, E., Stalenga, J., Toncea, I., Fitiu, A., Bucur, D., Lacko-Bartošová, M., \& Macák, M. (2018). Agroecology development in Eastern Europe Cases in Czech Republic, Bulgaria, Hungary, Poland, Romania, and Slovakia. Sustainability, 10:1311. doi: 10.3390/su10051311

Nagy, B. (1957). Importance of a biological view in plant pest control. [in Hungarian] A növényvédelem idöszerü kérdései, 2:1-10.

Németh, Gy., \& Székács, A. (2012). Comparison of the legal regulations of pesticides and hazardous chemicals in the European Union with emphasis on genotoxic and endocrine disrupting effects. Acta Phytopathologica et Entomologica Hungarica, 47(2):251-274. doi: 10.1556/ APhyt.47.2012.2.7

Nobelmann, M., Bálint, Cs., Chovanec, T., Evans, R., Hudcová, E., Jancsovszka, P., Moudrý, J., Pařízek, M., Schneider, C., Steininger, B., \& Ujj, A. (2020). Quality standards to teaching social farming. What future social farmers need to know to be successful. Retrieved from https://sofaredu.eu/wp-content/uploads/2020/02/QualityStandards-for-Teaching-Social-Farming.pdf

Parisi, S., Barone, C., \& Sharma, R.K. (2016). Chemistry and Food Safety in the EU. The Rapid Alert System for Food and Feed (RASFF). Springer Nature, Cham, Switzerland. doi: 10.1007/978-3319-33393-9 
Pigłowski, M. (2019). Comparative analysis of notifications regarding mycotoxins in the Rapid Alert System for Food and Feed (RASFF). Quality Assurance and Safety of Crops \& Foods, 11(8):725-735. doi: 10.3920/ QAS2018.1398

Podmaniczky, L., Vogt, J.V., Vogt, J.V., Schneller, K., \& Ángyán, J. (2007). Land suitability assessment methods for developing a European Land Information System for Agriculture and Environment (ELISA). In: Mander, Ü., Wiggering, H., \& Helming, K. (Ed.), Multifunctional Land Use: Meeting Future Demands for Landscape Goods and Services. Springer-Verlag, Berlin, Germany, pp 225250. doi: 10.1007/978-3-540-36763-5 14

Podmanicky, L., Balázs, K., Belényesi, M., Centeri, Cs., Kristof, D., \& Kohlheb, N. (2011). Modelling soil quality changes in Europe. An impact assessment of land use change on soil quality in Europe. Ecological Indicators, 11(1):4-15. doi: 10.1016/j.ecolind.2009.08.002

Searchinger, T.D., Wirsenius, S., Beringer, T., \& Dumas, P. (2018). Assessing the efficiency of changes in land use for mitigating climate change. Nature, 564:249-253. doi: 10.1038/ s41586-018-0757-z

Smith, L.G., Williams, A.G., \& Pearce, B.D. (2014). The energy efficiency of organic agriculture: A review. Renewable Agriculture and Food Systems, 30(3):280-301. doi: 10.1017/ S1742170513000471

Smith, L.G., Kirk, G.J.D., Jones, P.J., \& AWilliams, G. (2019). The greenhouse gas impacts of converting food production in England and Wales to organic methods. Nature Communications, 10:4641. doi: 10.1038/s41467-019-12622-7

Stern, V.M., Smith, R., van den Bosch, R., \& Hagen, K.S. (1959). The integrated control concept. Hilgardia, 29(2):81-101. doi: 10.3733/hilg. v29n02p081

Székács, A. (2013). External risks, practical implications and pitfalls of ecological agricultural practices and their relation to food safety. In: Drexler, D. (Ed.), 4th International Conference on Organic Agriculture Sciences (ICOAS). Book of Abstracts. Research Institute of Organic Agriculture, Buda- pest, Eger, Hungary, p. 60. Retrieved from http:// mek.oszk.hu/14600/14680/14680.pdf

Székács, A. (2020). Environmental analytical and ecotoxicological aspects of $B t$ maize in the Pannonian Biogeographical Region of the European Union. In: Hawksworth, D.L., Pessoa de Miranda, D.L. \& Chaurasia, A. (Ed.), GMOs: Implications for Biodiversity Conservation and Ecological Processes. Topics in Biodiversity and Conservation. Vol. 19. Springer Nature, Cham, Germany, pp. 149-172. doi: 10.1007/978-3-030-53183-6_7

Székács, A., Fónagy, A. , Fekete, G., Szentkirályi, F., \& Bernáth, B. (2004). Ecotoxicology and insect monitoring studies serving agroecology. [in Hungarian] AGRO-21 Füzetek, 37:148-159. Retrieved from http://nektar.oszk.hu/hu/manifestation/1010624

Székács, A., \& Darvas, B. (2012). Comparative aspects of Cry toxin usage in insect control. In: Ishaaya, I., Palli, S.R. \& Horowitz, R. (Ed.), Advanced Technologies for Managing Insect Pests. Springer-Verlag, Berlin, Germany, pp. 195-230. doi: 10.1007/978-94-007-4497-4_10

Székács, A., \& Darvas, B. (2018). Re-registration challenges of glyphosate in the European Union. Frontiers in Environmetal Science, 6:78. doi: 10.3389/fenvs.2018.00078

Székács, A., Mörtl, M., \& Darvas, B. (2015). Monitoring pesticide residues in surface and ground water in Hungary - surveys in 19902015. Journal of Chemistry, 2015:717948. doi: $10.1155 / 2015 / 717948$

Szelényi, G. (1955). Versuch einer Kategorisierung der Zoozönosen. Beiträge zur Entomologie 5:1835. doi: 10.21248/contrib.entomol.5.1-2.18-35

Ujj, A., Kléger, A., Pereira, R., Csapó, B., Moudrý, Jr., J., Chovanec, T., \& Bernas, J. (2018). Social farming in education. Hungarian Agricultural Research, 27(2):20-25. Retrieved from http://www.agrarlapok.hu/sites/default/files/ har_2018_02.pdf

Ujj, A., \& Bálint, Cs. (Ed.). (2020). Background report for agroecological vocational training. Retrieved from https://traece.eu/download/background-report-for-agroecological-vocationaltraining 
Ujj, A., Szabó, A., Csapó, B., \& Kléger, A. (2013). Vocational training in organic vegetable and fruit production - Support for improving organic farming education based on international cooperation (ECOVOC). In: Drexler, D. (Ed.), 4th International Conference on Organic Agriculture Sciences (ICOAS). Book of Abstracts. Research Institute of Organic Agriculture, Budapest, Eger, Hungary, p. 103. Retrieved from http://mek.oszk. hu/14600/14680/14680.pdf

Ujj, A., \& Fehér, I. (2015). Challenges of agroecology knowledge transfer in the higher education training programs in Hungary. Hungarian Agricultural Research, 24(4):9-19. Retrieved from http://www.agrarlapok.hu/sites/default/files/ har_2015_04.pdf

Várallyay, Gy. (2004). The Agroecology Research Program (Environmental interrelationships of agroecosystems and the possibilities of their control). [in Hungarian] AGRO-21 Füzetek, 37:5-22. Retrieved from http://nektar.oszk.hu/ hu/manifestation/1010624

Várallyay, Gy. (2010). Role of soil multifunctionality in sustainable development. Soil and Water Research, 5(3):102-107. doi: 10.17221/37/2009SWR

Várallyay, Gy., Szűcs, L. Zilahy, P., Rajkai, K., \& Murányi, A. (1985). Soil factors determining the agroecological potential of Hungary. Agrokémia és Talajtan, 34(Supp1.):90-94. Retrieved from http://real.mtak.hu/id/eprint/97636

Vida, G. (1996). General considerations on the biodiversity of urban and periurban environments. In: di Castri, F. Younes, T. (Ed.), Biodiversity, Science and Development: Towards a new Partnership. CAB International, Wallingford, UK, pp 581-583.

Wezel, A., \& Bellon, S. (2018). Mapping agroecology in Europe. New developments and applications. Sustainability, 10:2751. doi: 10.3390/ su10082751

Wezel, A., Bellon, S., Doré, T., Francis, C., Vallod, D., \& David, C. (2009). Agroecology as a science, a movement and a practice. A review. Agronomy for Sustainable Development, 29:503-515. doi: 10.1051/agro/2009004

Willer, H., \& Lernoud, J. (2019). The world of organic agriculture statistics and emerging trends 2019. Research Institute of Organic Agriculture (FiBL) and International Federation of Organic Agriculture Movements (IFOAM), Frick, Switzerland.

Woods, J., Williams, A., Hughes, J.K., Black, M., \& Murphy, R. (2010). Energy and the food system. Philosophical Transactions of the Royal Society B 365:2991-3006. doi: 10.1098/rstb.2010.0172 